\title{
HUBUNGAN ANTARA PENGETAHUAN TENTANG BOUNDING ATTACHMENT DENGAN SIKAP DALAM ROOMING IN PADA IBU NIFAS DI PUSKESMAS SIANTAN HILIR TAHUN 2016
}

\author{
Telly Katharina ${ }^{1}$, Katarina Iit $^{2}$
}

\author{
Akademi Kebidanan Panca Bhakti Pontianak \\ Email korespondensi: akbidpbpontianak@gmail.com
}

\begin{abstract}
Abstrak
Berdasarkan hasil wawancara yang dilakukan oleh peneliti terhadap beberapa orang ibu nifas di Puskesmas Siantan Hilir Pontianak ditemukan hasil sebagian besar dari ibu nifas tersebut mempunyai pengetahuan yang kurang tentang bounding attachment dan rooming in. Beberapa Ibu nifas tersebut juga memiliki sikap yang buruk terhadap bounding attachment seperti menyusui sambil memegang handphone, tidak memberikan asi karena keletihan setelah proses persalinan dan bahkan ada yang memarahi bayi ketika menangis. Padahal tindakan tersebut dapat mempengaruhi proses kelekatan dan bahkan akan membawa dampak buruk bagi bayi pada saat dewasa. Tujuan dari penelitian ini adalah untuk mengetahui hubungan antara pengetahuan tentang bounding attachment dengan sikap dalam rooming in pada ibu nifas di Puskesmas Siantan Hilir Pontianak tahun 2016. Penelitian ini menggunakan desain penelitian deskriptif korelasi dengan pendekatan crossectional. Penelitian ini dilakukan pada bulan desember sampai bulan April 2016 dengan jumlah sampel sebanyak 35 orang ibu nifas yang melakukan rooming in dengan bayinya. Hasil penelitian menunjukkan bahwa 20 responden $(57 \%)$ berpengetahuan cukup dan sebagian dari responden mendukung dalam rooming in. Hasil penelitian yaitu X2 hitung (1,991) 5,991 dan diperoleh nilai $\mathrm{P}$ value $=(0,370)(0,05)$ artinya tidak ada hubungan antara pengetahuan tentang bounding attachment dengan sikap dalam rooming in pada ibu nifas. Kesimpulan dari penelitian ini adalah tidak ada hubungan antara pengetahuan tentang bounding attachment dengan sikap dalam rooming in di Puskesmas Siantan Hilir Pontianak tahun 2016. Disarankan agar bidan dapat memberikan pemahaman dan informasi pada ibu nifas serta meningkatkan pelayanan kesehatan dengan melakukan penyuluhan dan tentang bounding attachment secara langsung pada ibu dan rooming in untuk bayi sehingga dapat terlaksana dengan baik.
\end{abstract}

Kata Kunci: Pengetahuan, Sikap, Bounding Attachment, Rooming In, Ibu Nifas

\section{Pendahuluan}

Ibu merupakan sosok perempuan yang paling berjasa dalam kehidupan seorang anak. Ibu adalah anggota keluarga yang berperan penting dalam mengatur semua terkait urusan rumah tangga, pendidikan anak dan kesehatan seluruh keluarga (Permenkes, 2014) dan hubungan ibu dengan anak dimulai sejak hamil, ketika ibu mengkhayal dan memimpikan dirinya sebagai ibu. Ibu ingin dekat, hangat, bercerita kepada bayinya dan mencoba membayangkan adanya tangisan bayi (Susanti, 2008).

\footnotetext{
${ }^{1}$ Dosen Akademi Kebidanan Panca Bhakti Pontianak

${ }^{2}$ Dosen Akademi Kebidanan Panca Bhakti Pontianak
}

Ketika seorang ibu hamil secara sadar mau dan mampu berkomunikasi dengan janin di dalam kandungannya, maka akan tercipta Bounding yang sangat kuat antara mereka. Setiap janin bisa berkomunikasi dengan ibunya dan setiap wanita hamil dapat berkomunikasi dengan bayinya didalam rahim. Setiap wanita hamil telah menangkap beberapa pesan dari bayinya secara sadar atau pun tidak (Aprillia, 2014).

Persalinan merupakan proses alamiah yang dialami perempuan, merupakan pengeluaran hasil konsepsi yang telah mampu hidup diluar 
kandungan melalui beberapa proses seperti adanya penipisan dan pembukaan serviks, serta adanya kontraksi yang berlangsung dalam waktu tertentu tanpa adanya penyulit (Marisah, 2011).

Proses persalinan merupakan proses yang sangat transformasional bagi seorang wanita, saat seorang wanita berubah status dan peran menjadi seorang ibu. Menciptakan pengalaman lahir dan persalinan yang positif merupakan awal yang baik dan merupakan kunci untuk masa depan (Aprillia, 2014).

Masa nifas atau puerperium dimulai sejak 1 jam setelah lahirnya plasenta sampai dengan 6 minggu (42 hari) setelah itu. Pelayanan pasca persalinan harus terselenggara pada masa itu untuk memenuhi kebutuhan ibu dan bayi, yang meliputi upaya pencegahan, deteksi dini dan pengobatan komplikasi dan penyakit yang mungkin terjadi serta penyediaan pelayanan pemberian ASI, cara menjarangkan kehamilan, imunisasi dan nutrisi bagi ibu (Prawirohardjo, 2010).

Masa nifas juga merupakan masa dimana kesempatan ibu dan bayi lahir ditempatkan disebelah tempat tidur ibu, dimaksudkan agar ibu segera dapat merespon dan memenuhi kebutuhan perawatan bagi bayinya. Misalnya dalam hal tangisan bayi, ibu dapat merespon tangisan bayi dan bertindak sesuai dengan tangisan tersebut, maka frekuensi bayi menangis akan berkurang dan bayi akan memiliki kemampuan lebih baik dalam menyesuaikan diri dengan lingkungan pasca lahir (Marmi,2014).
Bounding adalah suatu langkah untuk mengungkapkan perasaan areksi (kasih sayang) oleh ibu kepada bayinya segera setelah lahir sedangkan attachment adalah interaksi antara ibu dan bayi sepanjang waktu. Bounding attachment adalah kontak dini secara langsung antara ibu dan bayi setelah proses persalinan, dimulai kala III sampai dengan postpartum (Badriah, 2012).

Bayi yang dipisahkan dari ibunya segera setelah lahir, dapat menyulitkan perkembangan ikatan. Untuk itu, beberapa rumah sakit mencoba menggunakan suatu strategi kelahiran yang disebut "Rooming In" (sekamar dengan bayi). Rooming in sering juga disebut dengan rawat gabung yaitu menyatukan antara ibu dan bayinya dalam satu kamar, agar antara ibu dan bayinya terjalin suatu hubungan batin dan ibu bisa menjadi lebih dekat dengan bayinya (Marmi, 2014).

Rawat gabung mempunyai banyak keuntungan bagi ibu dan bayi antara lain menggalakkan pemakaian ASI, hubungan emosional pada ibu dan bayi lebih dini dan dekat, ibu dapat segera melaporkan kepada petugas kesehatan jika terjadi kelainan pada bayi, meningkatkan rasa percaya diri dan resiko infeksi silang dan nosokomial berkurang (Marmi, 2014).

Pengetahuan ibu tentang bounding attachment sangat penting jika pengetahuan ibu baik tentang manfaat bounding attachment maka ibu tersebut akan memberikan kasih sayang yang berlimpah terhadap bayinya (marisah, 2011).

Hal ini berkaitan erat dengan sikap ibu dalam melakukan bounding attachment, apabila ibu nifas mempunyai pengetahuan yang baik 
maka akan mempengaruhi sikap ibu dalam memberikan kasih sayang kepada bayinya sehingga bayi tersebut akan merasakan kasih sayang yang cukup serta dapat mempengaruhi pertumbuhan psikologis, intelektual serta sosial dalam kehidupannya kelak pada saat dewasa (Maulana, 2009).

Menurut Lutfi Dini Arasta pada tahun 2010 dengan judul "Hubungan Pelaksanaan Rawat Gabung Dengan Prilaku Ibu Dalam Memberikan Asi Ekslusif di Polindes Harapan Bunda Desa Kaligading” adalah dengan rawat gabung maka antara ibu dan bayi akan segera terjalin proses lekat (early infant - mother bounding) akibat sentuhan badan antara ibu dan bayi. Hal ini mempunyai pengaruh yang besar terhadap perkembangan psikologi bayi selanjutnya. Karena kehangatan tubuh ibu merupakan stimulasi mental yang mutlak dibutuhkan oleh bayi (Arasta, 2010).

Perbedaan Kemampuan Komunikasi Interpersonal Anak Ditinjau dari Attachment Terhadap Orang Tua di SDI Al Munawar" adalah Hubungan anak dengan orang tua merupakan sumber emosional dan kognitif bagi anak. Hubungan tersebut memberi kesempatan bagi anak untuk mengeksplorasi lingkungan maupun kehidupan sosial. Hubungan awal ini dimulai sejak anak terlahir kedunia. Bahkan sebetulnya sudah dimulai sejak janin berada dalam kandungan (Ajeng, 2012).

Banyak sekali tempat kesehatan pemerintahan yang menyediakan perawatan satu ruangan ibu bersama bayinya salah satunya adalah di Puskesmas Siantan Hilir. Tetapi di Puskesmas Siantan Hilir Pontianak belum memberikan penjelasan tentang bounding attachment sehingga ibu tersebut tidak maksimal dalam melakukan bounding attachment terhadap bayinya padahal apabila bounding attachment dapat terlaksana dengan baik maka akan menjadi pelajaran baginya untuk kelak diterapkan dalam kehidupannya setelah dewasa. Namun hubungan yang buruk menjadi pengalaman traumatis baginya sehingga menghalangi kemampuan dalam membina hubungan yang stabil dan harmonis dengan orang lain (Marisah, 2011).

Data dari Profil Kesehatan Indonesia (Data dan Informasi Kesehatan) pada tahun 2014 yaitu jumlah ibu bersalin di Indonesia berjumlah 4.918.303. Cakupan pertolongan persalinan oleh tenaga kesehatan dengan kompetensi kebidanan yaitu hanya sebanyak 4.493.383 dengan persentase $91,36 \%$ dan data jumlah ibu bersalin di Kalimantan yaitu sebanyak 307.063. ini menyatakan bahwa cakupan persalinan yang ditolong oleh tenaga kesehatan tidak sebanding dengan jumlah ibu bersalin (Kepmenkes, 2014).

Cakupan pertolongan persalinan oleh tenaga kesehatan di Kalimantan Barat telah mencapai $(59,48 \%)$. Berdasarkan data yang sama cakupan pertolongan persalinan oleh tenaga kesehatan di Kota Pontianak yaitu 67,49\%. Sedangkan target Renstra Kemenkes pada tahun 2014 ialah sebesar (90\%). Dari data tersebut telah menunjukkan bahwa cakupan pertolongan oleh tenaga kesehatan di Indonesia belum mencapai 
target yang telah ditetapkan (Kementrian Kesehatan RI, 2014).

Menurut Penelitian Mahardika Cahyaningrum pada tahun 2013 di RSUD Surakarta yang berjudul Tingkat Pengetahuan Ibu Nifas Tentang Bounding Attachment hasil penelitiannya pengetahuan baik sebanyak 4 responden $(8,5 \%)$, pengetahuan cukup sebanyak 29 responden $(61,7 \%)$ dan pengetahuan kurang sebanyak 14 responden (29,8\%). Berdasarkan hal tersebut maka mayoritas tingkat pengetahuan tentang bounding attachment adalah dalam kategori cukup (Cahyaningrum, 2013).

Demikian juga penelitian yang dilakukan oleh Susi Susanti pada tahun 2012 yang berjudul Gambaran Pengetahuan dan Sikap Ibu Postpartum Tentang Bounding Attachment di Rumah Sakit Islam Yarsi Pontianak hasil penelitian keseluruhan yang diperoleh dari sebagian kecil responden yang berpengetahuan baik sebanyak 3 orang (10\%), sedangkan yang berpengetahuan cukup sebanyak 10 orang (33\%), sebanyak 17 orang (57\%) berpengetahuan kurang. Sedangkan sikap yaitu $63 \%$ dari responden yang mendukung dan $37 \%$ dari responden yang tidak mendukung (Susanti, 2012).

Hasil studi pendahuluan di Puskesmas Siantan Hilir Pontianak diketahui bahwa jumlah persalinan dari bulan Januari sampai bulan Desember 2015 sebanyak 656 orang yaitu terdiri dari persalinan normal sebanyak 521 orang dan persalinan abnormal sebanyak 135 orang. Data ibu nifas yang melakukan rawat gabung yaitu sebanyak 656 orang yaitu tanpa membedakan bayi yang normal dan abnormal.

Hasil wawancara yang dilakukan oleh peneliti melalui wawancara terhadap beberapa orang ibu nifas yang berhasil penulis temui di Puskesmas Siantan Hilir Pontianak sebagian besar dari ibu nifas tersebut mempunyai pengetahuan yang kurang tentang bounding attachment dan rooming in. Beberapa Ibu nifas tersebut juga memiliki sikap yang buruk terhadap bounding attachment seperti menyusui sambil memegang handphone, tidak memberikan asi karena keletihan setelah proses persalinan dan bahkan ada yang memarahi bayi ketika menangis. Padahal tindakan tersebut dapat mempengaruhi proses kelekatan dan bahkan akan membawa dampak buruk bagi bayi pada saat dewasa.

\section{Metode}

Penelitian ini menggunakan jenis penelitian deskriptif korelasional dengan pendekatan cross sectional. Penelitian dilaksanakan pada bulan Januari hingga Mei 2016 di Puskesmas Siantan Hilir Pontianak. Populasi penelitian yaitu seluruh seluruh akseptor suntikan 3 bulan selama Januari sampai Maret 2016 sebanyak 140 orang. Peneliti menggunakan $25 \%$ jumlah populasi sebanyak 35 orang sebagai sampel. Pengumpulan data menggunakan kuesioner kemudian diolah dan dianalisis menggunakan analisis univariat serta analisis bivariat menggunakan uji chi square. 


\section{Hasil dan Pembahasan}

Tabel 1. Karakteristik Responden

\begin{tabular}{lcc}
\hline \multicolumn{1}{c}{ Karakteristik } & $\mathrm{n}$ & $\%$ \\
\hline Pengetahuan & & \\
Baik & 6 & 17 \\
Cukup & 20 & 57 \\
Kurang & 9 & 26 \\
Sikap & & \\
Mendukung & 21 & 60 \\
Tidak Mendukung & 14 & 40 \\
\hline
\end{tabular}

Berdasarkan tabel diatas dapat disimpulkan bahwa sikap responden dalam rooming in sebagian dari responden yaitu 17 responden (49\%) menjawab sangat setuju, sebagian kecil dari responden yaitu 22 responden (63\%) menjawab setuju, dan sebagian kecil dari responden yaitu 26 responden (74\%) menjawab tidak setuju, serta sebagian dari responden yaitu 15 responden (43\%) menjawab sangat tidak setuju. Data dari tabel diatas dapat disimpulkan bahwa sikap dalam rooming In pada ibu nifas adalah sebagian dari responden yaitu 21 responden (60\%) mendukung dalam rooming in pada ibu nifas.

Tabel 2. Analisis Bivariat

\begin{tabular}{|c|c|c|c|c|c|c|c|c|}
\hline \multirow{3}{*}{ Variabel } & \multicolumn{4}{|c|}{ Sikap Ibu Nifas } & & & \multirow{3}{*}{$\mathrm{X}_{2}$} & \multirow{3}{*}{ P Value } \\
\hline & \multicolumn{2}{|c|}{$\begin{array}{c}\text { Tidak } \\
\text { Mendukung }\end{array}$} & \multicolumn{2}{|c|}{ Mendukung } & \multicolumn{2}{|c|}{ Total } & & \\
\hline & $\mathrm{N}$ & $\%$ & $\mathrm{~N}$ & $\%$ & $\mathrm{~N}$ & $\%$ & & \\
\hline Kurang & 5 & 35,7 & 4 & 19,0 & 9 & 26 & & \\
\hline Pengetahuan Cukup & 6 & 42,9 & 14 & 66,7 & 20 & 57 & 1,991 & 0,370 \\
\hline Baik & 3 & 21,4 & 3 & 14,3 & 6 & 17 & & \\
\hline
\end{tabular}

Berdasarkan hasil pengolahan data diatas dengan menggunakan rumus Uji Chi square di dapatkan hitung 1,991sedangkan angka tabel $C h i$ Square taraf signifikasi 5\% db = 2 adalah 5, 991. Dengan demikian berarti $X_{2}$ hitung $(1,991) 5,991$ dan diperoleh nilai $\mathrm{P}$ value $=(0,370)(0,05)$ artinya tidak ada hubungan antara pengetahuan tentang bounding attachment dengan sikap dalam rooming in pada ibu nifas di Puskesmas Siantan Hilir Pontianak tahun 2016. Berdasarkan hasil penelitian terhadap ibu - ibu nifas didapatkan bahwa pengetahuan responden tentang bounding attachment dalam rooming in pada ibu nifas sangat sedikit dari responden yaitu 6 responden (17\%) berpengetahuan baik, sebagian dari responden yaitu 20 responden (57\%) berpengetahuan cukup dan sebagian kecil dari responden yaitu 9 responden (26\%) berpengetahuan kurang.

Hal ini sesuai dengan teori Notoadmodjo yang menyatakan bahwa pengetahuan seseorang akan baik apabila mendapat informasi yang baik juga sehingga informasi tersebut akan memberikan pengaruh pada tingkat pengetahuan seseorang (Notoadmodjo, 2010). 
Hasil penelitian diatas menunjukkan bahwa jawaban kuesioner yang diajukan ke responden dan didapatkan dari setiap pertanyaan di Puskesmas Siantan Hilir Pontianak didapatkan sebagian dari responden yaitu 22 responden (63\%) dapat menjawab dengan benar dan sebagian kecil dari responden yaitu 13 Responden (37\%) menjawab salah. Pengetahuan adalah merupakan hasil dari tahu, yang terjadi setelah orang melakukan pengindraan terhadap objek tertentu. Sebagian besar pengetahuan diperoleh melalui mata dan telinga. Pengetahuan merupakan pedoman dalam membentuk tindakan seseorang (overt behavior) (Maulana, 2009).

Hasil penelitian menunjukkan tingkat pengetahuan kurang sebagian kecil dari responden yaitu $26 \%$ hal ini disebabkan karena banyak responden yang belum mengetahui tentang bounding attachment hal ini dapat dibuktikan dari pertanyaan yang jawabannya salah pada no 9 sebagian dari responden yaitu $77 \%$.

Pengetahuan adalah hasil pengindraan manusia atau hasil tahu seseorang terhadap objek melalui indra yang dimiliki nya (mata, hidung, telinga dan sebagainya). Dengan sendirinya, pada waktu pengindraan sampai menghasilkan pengetahuan tersebut sangat dipengaruhi oleh intensitas perhatian dan persepsi terhadap objek (Notoadmodjo, 2010).

Pengetahuan pada dasarnya terdiri dari sejumlah fakta dan teori yang memungkinkan seseorang untuk dapat memecahkan masalah yang dihadapinya. Pengetahuan merupakan pedoman dalam membentuk tindakan seseorang (overt behavior) (Maulana, 2009).

Hasil penelitian yang dilakukan oleh Kurnia Mutiara (2013) di RS Ibu dan Anak Bereuneun Kabupaten Pidie didapatkan sebagian besar dari responden yaitu 20 responden $(52,6 \%)$ tentang bounding attachment dalam kategori kurang. Menurut asumsi peneliti bahwa pengetahuan yang baik didasari dari pengetahuan yang dimilikinya. Dengan ibu memiliki pendidikan yang tinggi maka ibu akan memperkaya dirinya dengan ilmu - ilmu yang berguna dalam perawatan bayi baru lahir.

Demikian juga hasil penelitian yang dilakukan oleh Yuliyanti tahun 2015 di BPS Yustina Sudarwati terhadap ibu - ibu nifas didapatkan bahwa pengetahuan responden tentang bounding attachment dalam rooming in pada ibu nifas sangat sedikit dari responden yaitu 8 responden $(22,9 \%)$ berpengetahuan baik, sebagian dari responden yaitu 21 responden (60\%) berpengetahuan cukup dan sebagian kecil dari responden yaitu 6 responden $(17,1 \%)$ berpengetahuan kurang.

Jadi kesimpulan dalam penelitian ini adalah pengetahuan ibu tentang bounding attachment dalam kategori cukup hal ini disebabkan oleh faktor pendidikan, umur dan pekerjaan yang merupakan salah satu faktor faktor yang dapat mempengaruhi pengetahuan. Selain itu pengetahuan ibu juga di pengaruhi oleh kurangnya informasi berupa pendidikan kesehatan tentang bounding attachment dari media elektronik ataupun media cetak khususnya 
tentang bounding attachment. Sehingga ibu kurang memahami tentang elemen - elemen, keuntungan, hambatan dan manfaat dari bounding attachment dari kuesioner yang telah diberikan.

Dari hasil penelitian melalui kuesioner tentang pernyataan sikap dalam rooming in di Puskesmas Siantan Hilir Pontianak sebagian dari responden yaitu 17 responden (49\%) menunjukkan bahwa sikap responden dalam rooming in menjawab sangat setuju, sebagian dari responden yaitu 22 responden (63\%) menjawab setuju, dan sebagian dari responden yaitu 26 responden (74\%) menjawab tidak setuju, serta sebagian dari responden yaitu 15 responden (43\%) menjawab sangat tidak setuju.

Hasil penelitian juga menunjukkan sebagian dari responden yaitu 21 responden (60\%) mendukung dan sebagian dari responden yaitu 14 responden (40\%) tidak mendukung dalam rooming in pada ibu nifas. Hal ini dapat dilihat dari pernyataan responden tentang bounding attachment dalam rooming in dengan kategori mendukung dan pernyataan dalam kategori tidak mendukung serta dari hasil jawaban pada pernyataan no 10 (pernyataan negatif) yang menjawab sangat setuju yaitu sangat sedikit dari responden (9\%). Dari pernyataan mengenai sikap ibu dalam rooming in menunjukkan sikap sudah terlihat baik namun masih perlu dilakukan pemberian informasi dengan konseling dan penyuluhan dari petugas kesehatan serta dari media cetak tentang bounding attachment dalam rooming in karena masih sebagian dari responden yaitu 14 responden (40\%) yang tidak mendukung terhadap bounding attachment dan rooming in.

Hal ini sesuai dengan teori Notoadmodjo (2007) yang menyatakan bahwa sikap merupakan reaksi atau respon yang masih tertutup dari seseorang terhadap satu stimulus dan objek. Manifestasi sikap itu tidak dapat langsung dilihat, tetapi hanya dapat ditafsirkan terlebih dahulu dari perilaku yang tertutup. Sikap secara nyata menunjukkan konotasi adanya kesesuaian reaksi terhadap stimulus tertentu yang dalam kehidupan sehari - hari merupakan reaksi yang bersifat emosional terhadap stimulus sosial (Notoadmodjo, 2007).

Hasil penelitian yang dilakukan oleh Susi Susanti pada tahun 2012 yang berjudul Gambaran Pengetahuan dan Sikap Ibu Post Partum Tentang Bounding Attachment di Rumah Sakit Islam Yarsi Pontianak di dapatkan hasil penelitian sikap sebagian dari responden yaitu $63 \%$ yang mendukung dan sebagian kecil dari responden yaitu 37\% yang tidak mendukung (Susanti, 2012).

Sikap merupakan kesiapan atau kesediaan untuk bertindak, yang menjadi predisposisi tindakan suatu perilaku, bukan pelaksanaan motif tertentu. Sikap merupakan kesiapan untuk bereaksi terhadap objek lingkungan tertentu sebagai suatu penghayatan terhadap objek (Wahit $\mathrm{dkk}, 2007)$.

Oleh karena itu dapat disimpulkan bahwa pengetahuan sangat berpengaruh terhadap sikap ibu nifas dalam memberikan kasih sayang kepada bayinya seperti membelai, mencium dan memberikan kasih sayang dalam suatu ruangan 
sehingga terjadi keterikatan psikologis antara ibu dan bayi semakin dekat karena dalam proses menyusui bayi, ibu nifas perlu mempunyai pengetahuan tentang cara pelaksanaan yang tepat dalam melakukan bounding attachment.

Dari hasil penelitian yang dilakukan oleh peneliti sebagian kecil dari responden yaitu 5 responden $(35,7 \%)$ mempunyai sikap tidak mendukung dan pengetahuan kurang, sebagian dari responden yaitu 6 responden $(42,9 \%)$ mempunyai sikap tidak mendukung dan pengetahuan cukup serta sebagian kecil dari responden yaitu 3 responden $(21,4 \%)$ mempunyai sikap yang tidak mendukung dan pengetahuan yang baik. Pada kategori sikap yang mendukung dan pengetahuan kurang sangat sedikit dari responden yaitu 4 responden $(19,0 \%)$ dan sebagian dari responden yaitu 6 responden $(42,9 \%)$ mempunyai sikap ibu yang mendukung dan pengetahuan cukup serta sangat sedikit dari responden yaitu 3 responden (14,3\%) responden yang mempunyai sikap mendukung dan pengetahuan yang baik.

Berdasarkan hasil pengolahan data dengan menggunakan rumus Uji Chi square di dapatkan hitung 1,991sedangkan angka tabel Chi Square taraf signifikasi 5\% db $=2$ adalah 5, 991. Dengan demikian berarti $\mathrm{X}_{2}$ hitung (1,999) 5,991 dan diperoleh nilai $\mathrm{P}$ value $=(0,370)(0,05)$, artinya tidak ada hubungan antara pengetahuan tentang bounding attachment dengan sikap dalam rooming in pada ibu nifas di Puskesmas Siantan Hilir Pontianak tahun 2016.
Walaupun hasil statistik tidak ada hubungan namun, data memperlihatkan bahwa sebagian kecil dari responden yaitu 5 responden $(35,7 \%)$ mempunyai sikap tidak mendukung dan pengetahuan kurang, sebagian dari responden yaitu 6 responden $(42,9 \%)$ mempunyai sikap yang tidak mendukung dan pengetahuan cukup serta sebagian kecil dari responden yaitu 3 responden $(21,4 \%)$ mempunyai sikap yang tidak mendukung dan pengetahuan yang baik. Pada kategori sikap sangat sedikit dari responden yaitu 4 responden $(19,0 \%)$ mempunyai sikap yang mendukung dan pengetahuan kurang, sebagian dari responden yaitu 6 responden $(42,9 \%)$ mempunyai sikap yang mendukung dan pengetahuan cukup serta sebagian kecil dari responden yaitu 3 responden $(14,3 \%)$ mempunyai sikap yang mendukung dan pengetahuan yang baik.

Hal ini sesuai dengan teori Maulana (2009) yang mengatakan bahwa sikap terbentuk secara bertahap, diawali dari pengetahuan dan pengalaman terhadap objek sikap tertentu. Sikap tidak dibawa sejak lahir tetapi dipelajari dan dibentuk berdasarkan pengalaman dan latihan sepanjang perkembangan individu.

Hal ini menunjukkan bahwa sikap sangat berkaitan erat dengan tingkat pengetahuan seseorang. Sikap seseorang terhadap suatu objek menunjukkan tingkat pengetahuan tersebut terhadap objek yang bersangkutan. Dengan demikian dapat disimpulkan bahwa ibu nifas yang berpengetahuan baik tentang bounding attachment memiliki kecendrungan mempunyai sikap yang positif (Notoadmodjo, 2007). 
Hal ini sesuai dengan hasil penelitian Lestari Dwi pada tahun 2012 di RSUD Dr. Moewardi yang berjudul Hubungan Tingkat Pengetahuan Dengan Sikap Ibu Dalam Mobilisasi Dini Pasca Sectio Caesaria hasil penelitiannya sebagian kecil dari responden yaitu 39 responden $(36,8 \%)$ mempunyai pengetahuan tinggi dan sebagian dari responden yaitu 67 responden $(63,2 \%)$ mempunyai pengetahuan rendah. sebagian kecil dari responden yaitu 31 responden (29,2\%) mempunyai sikap yang baik dan sebagian dari responden yaitu 75 responden (70,8\%) mempunyai sikap yang kurang tentang mobilisasi pasca section caesaria. Hasil uji statistik diperoleh nilai $\mathrm{r}=0,385$ dengan nilai signifikasi $\mathrm{p}=0,000$. Maka kesimpulannya adalah terdapat hubungan tingkat pengetahuan dengan sikap ibu dalam mobilisasi dini pasca section caesaria (Lestari, 2012).

Dengan sikap secara minimal, masyarakat memiliki pola berpikir tertentu dan pola berpikir diharapkan dapat berubah dengan diperolehnya pengalaman, pendidikan, dan pengetahuan melalui interaksi dengan lingkungannya. Sikap terbentuk secara bertahap diawali dari pengetahuan dan pengalaman terhadap objek sikap tertentu (Maulana, 2009).

Hal ini tidak sesuai dengan hasil penelitian yang dilakukan oleh Chahyani pada tahun 2015 yaitu sebagian kecil dari responden $(29,6 \%)$ mempunyai pengetahuan yang tinggi dan memiliki sikap yang positif sedangkan sebagian kecil dari responden (23\%) memiliki pengetahuan yang rendah dan memiliki sikap yang negative.
Berdasarkan hasil uji analisis uji statistik p value chi square didapatkan $p$ value $=0,551$ dan nilai $\mathrm{p}$ $=0,05$ sehingga dapat disimpulkan bahwa tidak ada hubungan antara tingkat pengetahuan dengan sikap mahasiswa regular di RUU keperawatan. Hal ini sependapat dengan teori Notoadmodjo (2010) yang mengatakan bahwa sikap dapat dipengaruhi oleh kepercayaan atau keyakinan artinya bagaimana keyakinan, pendapat atau pemikiran seseorang terhadap suatu objek. Kemudian penilaian ibu nifas terhadap suatu objek seperti bagaimana ibu dalam memberikan kasih sayang kepada bayinya (Notoadmodjo, 2010).

\section{Kesimpulan}

Jadi kesimpulan dalam penelitian ini adalah tidak ada hubungan antara pengetahuan tentang bounding attachment dengan sikap ibu dalam rooming in di Puskesmas Siantan Hilir Pontianak tahun 2016. Hal ini karena jumlah sampel populasi hanya sedikit yaitu sebanyak 35 responden sehingga tidak dapat mewakili populasi yang ditentukan. Selain itu dari hasil penelitian diatas menunjukkan tingkat pengetahuan yang baik belum tentu memiliki sikap yang mendukung karena pemikiran ibu yang sudah dipengaruhi oleh perubahan zaman globalisasi sehingga wanita lebih sibuk dengan kecantikan, gadget dan pekerjaannya sehingga ibu tidak mementingkan akan manfaat dari bounding attachment bagi perkembangan bayinya seperti dapat meningkatkan rasa percaya diri, membina hubungan yang hangat setelah dewasa, 
disiplin, dan hubungan pertumbuhan intelektual dan psikologi. Jadi solusinya adalah tenaga kesehatan lebih meningkatkan pemberian informasi tentang bounding attachment dengan pendidikan kesehatan seperti pemberian konseling dan penyuluhan ataupun dengan pemberian informasi melalui media cetak maupun elektronik. Sehingga ibu yang pengetahuannya kurang tentang bounding attachment menjadi lebih baik lagi sehingga bonding attachment dapat terlaksana dengan baik.

\section{Daftar Pustaka}

Ajeng dan Meita, 2012. Perbedaan Kemampuan Komunikasi Interpersonal Anak Ditinjau dari Attachment TerhadapOrang Tua. ejournal.unesa.ac.id/article/3502/17/ article.pdf. Diakses tanggal 1 maret 2016, 17.50

Aulia, A. 2012. Gambaran tingkat pengetahuan ibu nifas tentang bounding attachment. digilib.stikeskusumahusada.ac.id/downloa d.php?id=228. Diakses tanggal 5 maret 2016, 19.30

Aprillia, Y. 2014. Gentle Birth Balance. PT. Mizan Pustaka : Bandung

Arasta,D.L. 2010. Hubungan Pelaksanaan Rawat Gabung Dengan Prilaku Ibu Dalam Memberikan Asi Ekslusif. ejournal.akbid-

purworejo.ac.id/index.php/jkk4/articl e/view/64/62) Diakses tanggal 2 maret 2016, 22.32

Arikunto, 2006. Prosedur Penelitian Suatu Pendekatan Praktik. PT. Asdi Mahasatya : Jakarta

Ardial, 2014. Paradigma dan Model Penelitian Komunikasi. Jakarta Bumi Aksara
Badriah, dkk. 2012. Asuhan Persalinan Normal Bagi Bidan. Bandung. PT Refika Aditama

Cahyaningrum, 2013. Tingkat Pengetahuan Ibu Nifas Tentang Bounding Attachment.digilib.stikeskusumahusad a.ac.id/download.php?id=346. diakses tanggal 2 maret 2016, 23.50

Dewi, V. 2013. Asuhan Neonatus Bayi dan Anak Balita. Jakarta : Salemba Medika

Heryani, R. 2010. Asuhan Kebidanan Ibu Nifas dan Menyusui. CV. Trans Info Media : Jakarta

Hidayat. A. A, 2014. Metode Penelitian Kebidanan dan Teknik Analisa Data. Jakarta : Salemba Medika

Chahyani Isti, 2012. Hubungan tingkat pengetahuan dengan sikap mahasiswa regular FIK UI terhadap RUU Keperawatan. lib.ui.ac.id/file?file=digital/20299357S1984-Isti\%20Cahyani.pdf. Diakses tanggal 2 maret 2016, 12.30

Kementrian Kesehatan RI, 2014. Ringkasan EksekutifData dan Informasi Kesehatan Provinsi Kal - bar. Diakses tanggal 2 maret 2016, 12.30

.2014.RenstraKemenkes.www. depkes.go.id/resources/download/infopubl ik/Renstra2015.pdf). Diakses tanggal 2 maret 2016, 12.30

.2014.Infodatinibu.www.depke s.go.id/download.php?file.../infodatin/info datin-ibu.pdf). Diakses tanggal 3 maret 2016

2014.Pusdatin.www.pusdatin.k emkes.go.id/...in donesia/data-daninformasi2014.pdf). Diakses tanggal 8 maret 2015

Lestari, D. 2012. Hubungan Tingkat Pengetahuan Dengan Sikap Ibu Dalam Mobilisasi Dini Pasca Sectio Caesaria. 
eprints.ums.ac.id/21980/14/nask

ah_publikasi.pdf. Diakses tanggal 25 maret 2016, 22.40

Liliweri, A. 2007. Dasar - Dasar Komunikasi Kesehatan. Yogyakarta: Pustaka Belajar

Marmi, 2014. Asuhan Neonatus, Bayi, Balita dan anak pra sekolah. Pustaka Belajar: Yogjakarta

Marisah, Reni. R. 2011.Asuhan Kebidanan pada Masa Persalinan. Jakarta: Salemba Medika

Maulana. 2009. Promosi Kesehatan. Jakarta EGC

Mutiara, 2013. Hubungan Paritas, pengetahuan dan pendidikan dengan bounding attachment pada ibu nifas di Rumah Sakit Ibu dan Anak Bereuneun Kabeupaten Pidie.

simtakp.uui.ac.id/docjurnal/kurni_mutiara -jurnal.pdf. Diakses tanggal 8 maret 2015

Notoatmodjo. 2007. Ilmu \& Seni Kesehatan Masyarakat. Jakarta. PT Rineka Cipta

PT. Rineka Cipta , 2010. Promosi Kesehatan. Jakarta: ,2010. Metodologi Penelitian Kesehatan. Jakarta: PT. Rineka Cipta

Prawirohardjo, Sarwono. 2010. Ilmu Kebidanan. Jakarta: PT. Bina Pustaka.

Saryono dan Ari. 2011. Metodologi Penelitian Kebidanan.Yogyakarta: Nuha Medika

Sugiyono. 2010. Statistik Untuk Penelitian. Alfabeta: Bandung

Suyanto dan Susila. 2014. Metodolgi Penelitian Cross Sectional Kedokteran dan Kesehatan. Bossscript: Klaten

Susanti, Nengah. 2008. Psikologi Kehamilan. Jakarta: EGC

Susanti 2012. Gambaran Pengetahuan dan Sikap Ibu Post Partum Tentang Bounding Attachment di Rumah Sakit Islam
Yarsi. Karya Tulis Ilmiah. Akademi Kebidanan Panca Bhakti Pontianak (tidak dipublikasikan)

Tri dan Vivian. 2011. Asuhan Kebidanan pada Masa Nifas. Jakarta: Salemba Medika

Varney,H. 2008. Buku Ajar Asuhan Kebidanan. Jakarta: EGC

Wahit dkk. 2007. Promosi Kesehatan: Sebuah Pengantar Proses Belajar Mengajar dalam Pendidikan. Graha ilmu: Yogjakarta

Yuliyanti. 2015. Tingkat Pengetahuan Ibu Nifas Tentang

BoundingAttachment.www.digilib.stikesk u sumahusada.ac.id/download.php ?id=1035. Diakses tanggal 1maret 2016, 17.50 